\title{
Changes in the Abundance and Size of Skates in the Southern Gulf of St. Lawrence, 1971-2002
}

\author{
D. P. Swain, T. Hurlbut and H. P. Benoît \\ Fisheries and Oceans Canada, Gulf Fisheries Centre, P. O. Box 5030 \\ 343 University Avenue, Moncton, New Brunswick E1C 9B6
}

Swain, D. P., T. Hurlburt, and H. P. Benoît. 2005. Changes in the abundance and size of skates in the Southern Gulf of St. Lawrence, 1971-2002. J. Northw. Atl. Fish. Sci., 36: 19-30. doi: 10.2960/J.v36. m552

\begin{abstract}
Three species of skates commonly occur in the southern Gulf of St. Lawrence: thorny skate Amblyraja radiata, winter skate Leucoraja ocellata, and smooth skate Malacoraja senta. Trends in their abundance and size are described using data from annual bottom-trawl surveys conducted each September since 1971. Biomass and the abundance of mature skates decreased over the 1971-2002 period, by $80-90 \%$ for thorny and winter skates, and to a lesser degree for smooth skates. Abundance of juvenile thorny and smooth skates increased from the mid-1980s to a peak in the mid-1990s, and then declined in the late1990s. Mean length decreased by 20-30\% during the 1980s for each of the three species. The increase in the abundance of juvenile skates in the 1990s coincided with a collapse in the biomass of large-bodied demersal teleost fishes, a dramatic decline in fishing effort, a cooling of the cold intermediate layer in the southern Gulf and decreasing abundance of mature skates. The decline in the abundance of large skates may be an effect of fishing, though reported landings of skates have been low. These results for the southern Gulf of St. Lawrence contrast those observed on Georges Bank and in the North Sea, where small elasmobranch species that were not targeted by fisheries increased in biomass as the biomass of heavily exploited groundfish stocks declined.

Key words: elasmobranchs, indirect effects of fishing, non-target species, population declines, species replacement
\end{abstract}

\section{Introduction}

Concerns have been raised over the impact of fishing on shark and ray populations around the world (e.g., Stevens et al., 2000). Late age-at-maturity, low fecundity and slow growth make these fishes particularly vulnerable to over-exploitation (Holden, 1973; Stevens et al., 2000). As predicted from these life-history characteristics, large species, such as the common skate Dipturus batis and the barndoor skate $D$. laevis, have been severely depleted by fishing, either locally (Brander, 1981; Walker and Hislop, 1998) or throughout their range (Casey and Myers, 1998).

In contrast to the larger species, the thorny skate Amblyraja radiata has increased in abundance in the North Sea in recent times (Heessen and Daan, 1996; Walker and Heessen, 1996; Walker and Hislop, 1998). This species matures at a shorter length and earlier age than other skates in the North Sea and is thus expected to be the most resilient of the North Sea skates to fishing (Walker and Hislop, 1998). Thorny skates are caught as by-catch in North Sea fisheries but, unlike other skates, are usually discarded because of their small size (Heessen and Daan, 1996; Walker and Hislop, 1998). The survival rate of discarded skates is thought to be quite high (Walker and Hislop, 1998). Enhanced food availability, either due to reduced interspecific competition as a result of fishery removals of large teleost fishes or due to access to large quantities of discarded fishery catch, has been suggested as a possible explanation for the recent increase in abundance of thorny skate in the North Sea (Walker and Heessen, 1996; Walker and Hislop, 1998).

Small elasmobranch species (dogfish sharks and skates) also increased in abundance on Georges Bank, coincident with declines in the biomass of exploited groundfish populations (Fogarty and Murawski, 1998). As suggested for the North Sea, this increase in elasmobranch biomass may have resulted from a release from interspecific competition with depleted groundfish species (e.g., Murawski and Idoine, 1992), though the extent to which resources such as food or space are limiting in the area is uncertain (Fogarty and Murawski, 1998). Alternatively, changes in elasmobranch biomass on Georges Bank may reflect effects of fishing. Beginning in the early 1960s, distant-water fleets of factory trawlers operated on Georges Bank, retaining small elasmobranchs as part of their catch until they were excluded from this area in 1977. Thus, the increase in the abundance of small elasmobranchs on Georges Bank in the 1980s may reflect reduced fishing mortality following the exclusion of the 
distant-water fleets in 1977. Although caught incidentally by the domestic fleet, dogfish and skates were generally discarded at sea until recently. However, increased landings of elasmobranchs by the domestic fleet in recent years have coincided with a decline in their biomass on the Bank (Fogarty and Murawski, 1998).

These observations from the North Sea and Georges Bank suggest that, while large skates with late ages-atmaturity may be rapidly depleted by fisheries, smaller earlier-maturing skates that are not targeted by fisheries may benefit from indirect effects of fishing such as the removal of competing teleost fishes. In this paper, we describe changes in the abundance and size composition of skates in the southern Gulf of St. Lawrence between 1971 and 2002. Three species are examined: winter skate Leucoraja ocellata, smooth skate Malacoraja senta and thorny skate $A$. radiata. We compare changes in the biomass of these skates with changes in 1) the biomass of demersal teleost fishes and seals, potential competitors or predators of skates, 2) indices of environmental conditions and 3) reported landings of skates.

\section{Material and Methods}

\section{Data Sources}

Data are from annual bottom trawl surveys conducted in the southern Gulf of St. Lawrence each September since 1971. Surveys used a stratified random design, with stratification based on depth and geographic region. Surveys covered a depth range of about 20-375 m (Fig. 1). During these surveys, trawling was conducted at 63-74 sites in each year from 1971 to $1983,82-132$ sites from 1984 to 1988, and 141-202 sites from 1989 to 2002. The target fishing procedure in all years was a 30 -min tow at 3.5 knots. All catches were adjusted to a standard tow of 1.75 naut. miles. Surveys were conducted by the research vessel E. E. Prince using a Yankee 36 trawl from 1971 to 1985, by the Lady Hammond using a Western IIA trawl in 1985 to 1991, and by the Alfred Needler using a Western IIA trawl since 1992. These vessels and trawls are described by Nielsen (1994). Relative fishing efficiency between these vessels and gears was estimated from comparative fishing experiments conducted during or before the September survey. No differences in fishing efficiency for skates were detected, except for a tendency for the Alfred Needler to be less efficient than the Lady Hammond at catching thorny skate $(P=0.015$; Benoît and Swain, 2003a). Catches of thorny skate by the Alfred Needler were adjusted to be equivalent to those by the Lady Hammond following Benoît and Swain (2003a).

Fishing was conducted only during daylight hours (07:00-19:00) in the period 1971-84, but done throughout the 24-hr day since 1985. Catches were adjusted for diel differences in fishing efficiency, as described in Benoit and Swain (2003b). All three species had higher catchability at night than in day, and night catches were adjusted to be equivalent to day catches. These adjustments were length-dependent, with greater adjustment at smaller lengths, for thorny skate for surveys conducted by both the Lady Hammond and the Alfred Needler, and for winter skate for surveys conducted by the Lady Hammond, and independent of length in other cases (see Benoît and Swain (2003b) for details).

\section{Study Area and Populations}

The southern Gulf of St. Lawrence consists of the Magdalen Shallows, a shallow shelf with depths mostly under $100 \mathrm{~m}$, bordered by a 450-m trench, the Laurentian Channel (Fig. 1a). In summer and early autumn, the waters of the southern Gulf consist of three layers: a warm surface layer, a cold intermediate layer (the CIL, at depths of about 30-100 m), and a warm deep layer (Gilbert and Pettigrew, 1997). The CIL covers the bottom over much of the Magdalen Shallows. In winter, the southern Gulf is typically ice-covered, and two water layers are present; a cold layer with temperatures near the freezing point that covers the bottom over most of the Shallows, and a warm deep layer along the slope of the Laurentian Channel.

Three species of skate commonly occur in the southern Gulf of St. Lawrence: thorny skate, winter skate and smooth skate. Thorny skate is the most abundant of the three species, and is typically widely distributed throughout the Magdalen Shallows (Fig. 1b). In summer and early autumn, winter skate are found primarily in shallow inshore waters (Fig. 1c), with most individuals caught at depths less than $40 \mathrm{~m}$. In contrast, smooth skate are confined to deep waters (Fig. 1d), with most individuals found deeper than $100 \mathrm{~m}$.

Thorny skate migrate into the deeper waters of the Laurentian Channel in late autumn, moving back into shallower waters in May (Clay, 1991; Darbyson and Benoît, 2003). Winter skate also move offshore in winter, when they are distributed widely throughout the Magdalen Shallows in waters less than $200 \mathrm{~m}$. In contrast, smooth skate show little seasonal movement, with highest concentrations in relatively deep waters throughout the year.

Growth and maturation have not been well studied for skates in the Gulf of St. Lawrence. Templeman (1987) reported lengths at $50 \%$ maturity $\left(L_{50}\right)$ of $50-56 \mathrm{~cm}$ for thorny skate in the Gulf of St. Lawrence. On the northeastern Scotian Shelf, the region directly east of the southern Gulf of St Lawrence, length of maturity is about $50 \mathrm{~cm}$ for female thorny skate (Simon and Frank, MS 1996). Winter 


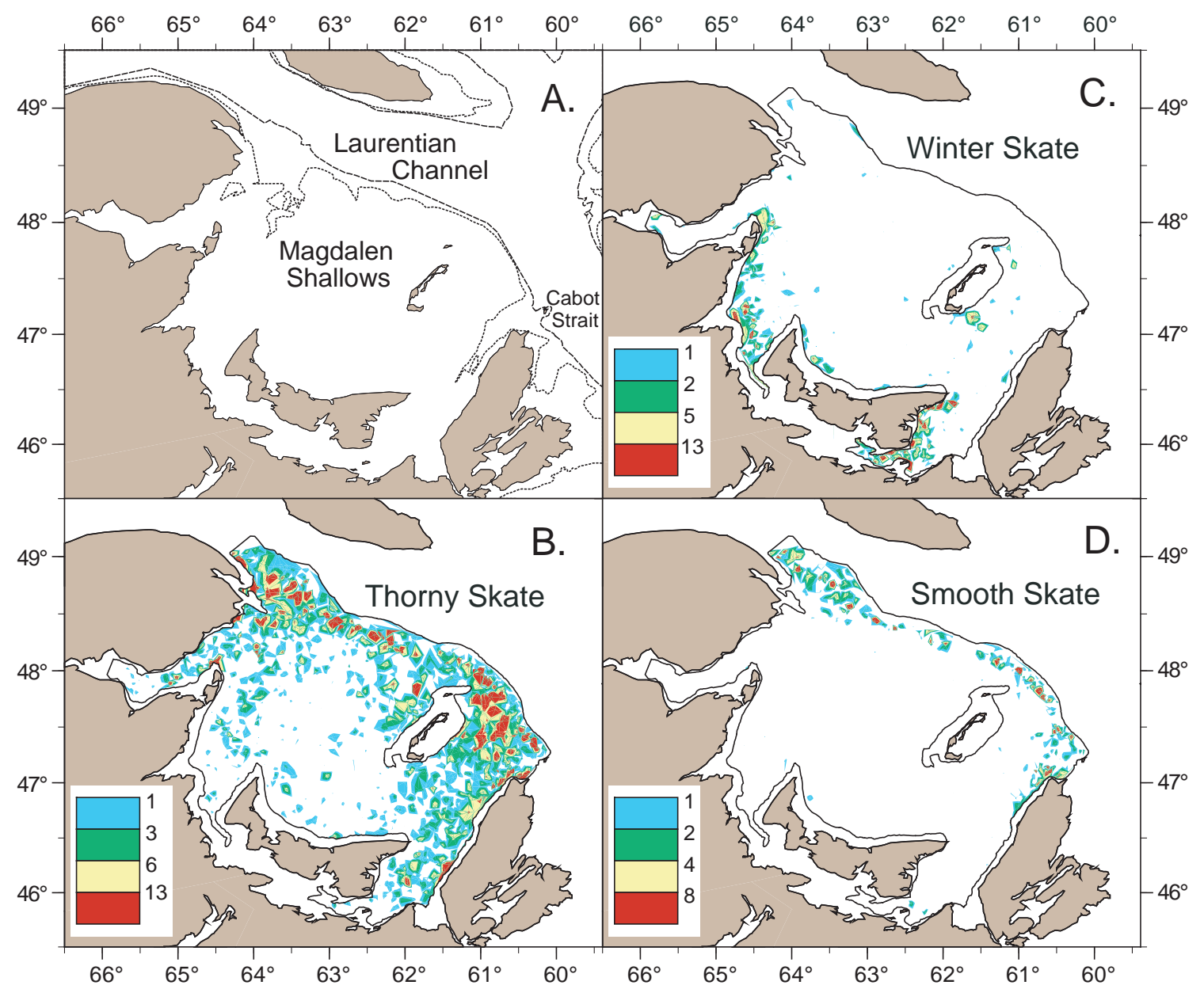

Fig. 1. Maps of the southern Gulf of St. Lawrence, Canada, showing (A) place names and depth contours, and (B) the average density (kg/tow) of thorny, (C) winter and (D) smooth skates in September, 1971-2002. The September survey area is outlined in panels B-D. Dotted and dashed lines in panel A are the 100 and $200 \mathrm{~m}$ contours, respectively.

skate in the Gulf are also mature at lengths greater than $50 \mathrm{~cm}$, though length at maturity is considerably greater for this species in other areas (McEachran and Martin, 1977). No ageing studies have been conducted on skates in the Gulf of St. Lawrence. In other areas, age of maturity is about 5 years for thorny skate and 9 years for winter skate, with a maximum age of about 20 years for both species (Frisk et al. 2004).

\section{Abundance Indices and Size Composition}

Length distributions were determined for each tow in 3 -cm intervals. For each year, the stratified mean catch per tow was calculated for each length interval:

$$
\overline{Y_{l}}=\sum_{k=1}^{S} \sum_{j=1}^{N_{k}} \sum_{i=1}^{n_{j}} \frac{w_{k}}{N_{k} n_{j}} Y_{i j k l}
$$

where $Y_{i j k l}$ is the number of fish in length interval $l$ caught in tow $i$ at site $j$ in stratum $k, w_{k}$ is the proportion of the survey area covered by stratum $k, N_{k}$ is the number of sites sampled in stratum $k, n_{i}$ is the number of tows conducted at site $j$, and $S$ is the number of strata. These length distributions were summed to give the total stratified mean catch per tow for each year, as well as the mean within each of three length groups: $<33 \mathrm{~cm}, 33-50 \mathrm{~cm}$ and $>50 \mathrm{~cm}$. Based on the earlier studies of length at maturity, the larger size group corresponds roughly to the mature population, at least for thorny and winter skates.

Length distributions were also converted to biomass using length-weight relationships. These relationships were estimated from measurements on individual skates obtained during each survey. Annual relationships were 
estimated for thorny skate. Because data were sparser for winter and smooth skates, separate length-weight relationships were estimated for blocks of five years, rather than for individual years, for these species.

\section{Analyses}

Trends in abundance, biomass and mean length were assessed using generalized additive models (GAMs). A Poisson error model was used in analyses of catch rates because their variance tended to increase with their mean. A scale parameter was estimated to allow for over or under dispersion. A Gaussian error model was used in analyses of mean length because variance appeared to be relatively homogeneous over the range of mean lengths observed here. A cubic spline smoother with degrees of freedom set to 4 was used in both cases. Statistical significance of trends was assessed by analysis of deviance, using the F-test described by Venables and Ripley (1994). Models were fit using S-Plus (Mathsoft, 1999).

An exponential decay model was also fitted to selected time series using nonlinear least squares:

$$
N_{t}=N_{0} e^{-\mathrm{d} t}
$$

where $N_{0}$ is abundance or biomass in 1970, $t$ is the time in years since 1970 and $\delta$ is the estimated rate of decline. $\delta$ can be used to calculate an estimate of the percent decline over $t$ years $(\Delta)$ :

$$
\Delta=100 \cdot\left(1-e^{-\delta t}\right)
$$

Time series of skate abundance and various potential explanatory variables were compared. Common trends in skate abundance were estimated using dynamic factor analysis (DFA), a dimension-reduction technique designed for time series data (Zuur et al., 2003). DFA was conducted using the software package Brodgar (www.brodgar.com). Skate abundance data were fourth root transformed and normalized (to a mean of 0 and standard deviation of 1 ) prior to calculating common trends. Cross correlations were calculated between the common trends and the possible explanatory variables, with the latter lagged 0-8 years.

Potential explanatory variables included indices of demersal fish biomass, seal abundance and environmental conditions. Catch rates (stratified mean $\mathrm{kg} /$ tow) in the annual survey were used as biomass indices for the main demersal teleost fishes: Atlantic cod Gadus morhua, white hake Urophycis tenuis, American plaice Hippoglossoides platessoides, witch flounder Glyptocephalus cynoglossus, Greenland halibut Reinhardtius hippoglossoides, Atlantic halibut Hippoglossus hippoglossus, winter flounder Pseudopleuronectes americanus, yellowtail flounder
Limanda ferruginea, and redfish Sebastes spp. Together with the skates, these fishes account for $95 \%$ of the biomass of demersal fishes caught by the survey.

Estimates of the abundance of grey seals Halichoerus grypus in the Gulf of St. Lawrence were obtained from Chouinard et al. (2005). Hammill and Stenson (2000) concluded that grey seals dominated predation by seals in the southern Gulf of St Lawrence. Harp seals Phoca groenlandica are also abundant in the Gulf of St. Lawrence in winter and spring (Hammill and Stenson, MS 2002). However, time series of estimated abundance are available only for the entire Atlantic Canadian harp seal herd, and not for the portion of the herd entering the Gulf of St. Lawrence each winter. Thus, our analyses are restricted to relationships with estimated grey seal abundance in the Gulf. Nonetheless, we believe these estimates may provide a reasonable index of the overall abundance of seals in the Gulf of St. Lawrence, because estimates of abundance of the Gulf grey seal herd and the Atlantic Canadian harp seal herd are strongly correlated over the 1971-2000 period $\left(R^{2}=0.98\right)$. Fish biomass and seal abundance indices were ln-transformed prior to use in analyses.

The mean minimum CIL temperature over the Magdalen Shallows (Gilbert and Pettigrew, 1997) and the annual average temperature in the 200-300 m layer in the Cabot Strait (Drinkwater and Gilbert, 2004) were used as indices of environmental conditions. Because time series of fishing mortality are not available for skates in the southern Gulf of St. Lawrence, an examination of possible fishery effects on skate abundance is deferred to the Discussion.

\section{Results}

\section{Abundance and Biomass Trends}

Abundance and biomass of winter skate both declined steadily throughout the 1980s and 1990s, reaching very low levels in recent years (Fig. 2). The exponential model indicated an $87 \%$ decline in winter skate biomass since the early 1970s (Table 1). Time trends in abundance and biomass showed contrasting patterns for thorny and smooth skates. For both species, abundance declined to relatively low values in the early 1980s, but then increased to a peak in the mid-1990s, followed by a decline to low values in recent years. In contrast, biomass of thorny skate declined steadily throughout the 32-year time series (Fig. 2), decreasing by about $84 \%$ over this period (Table 1). On the other hand, no significant trend in the biomass of smooth skate occurred over this period, both according to the GAM (Fig. 2) and the exponential decay model (Table 1). 

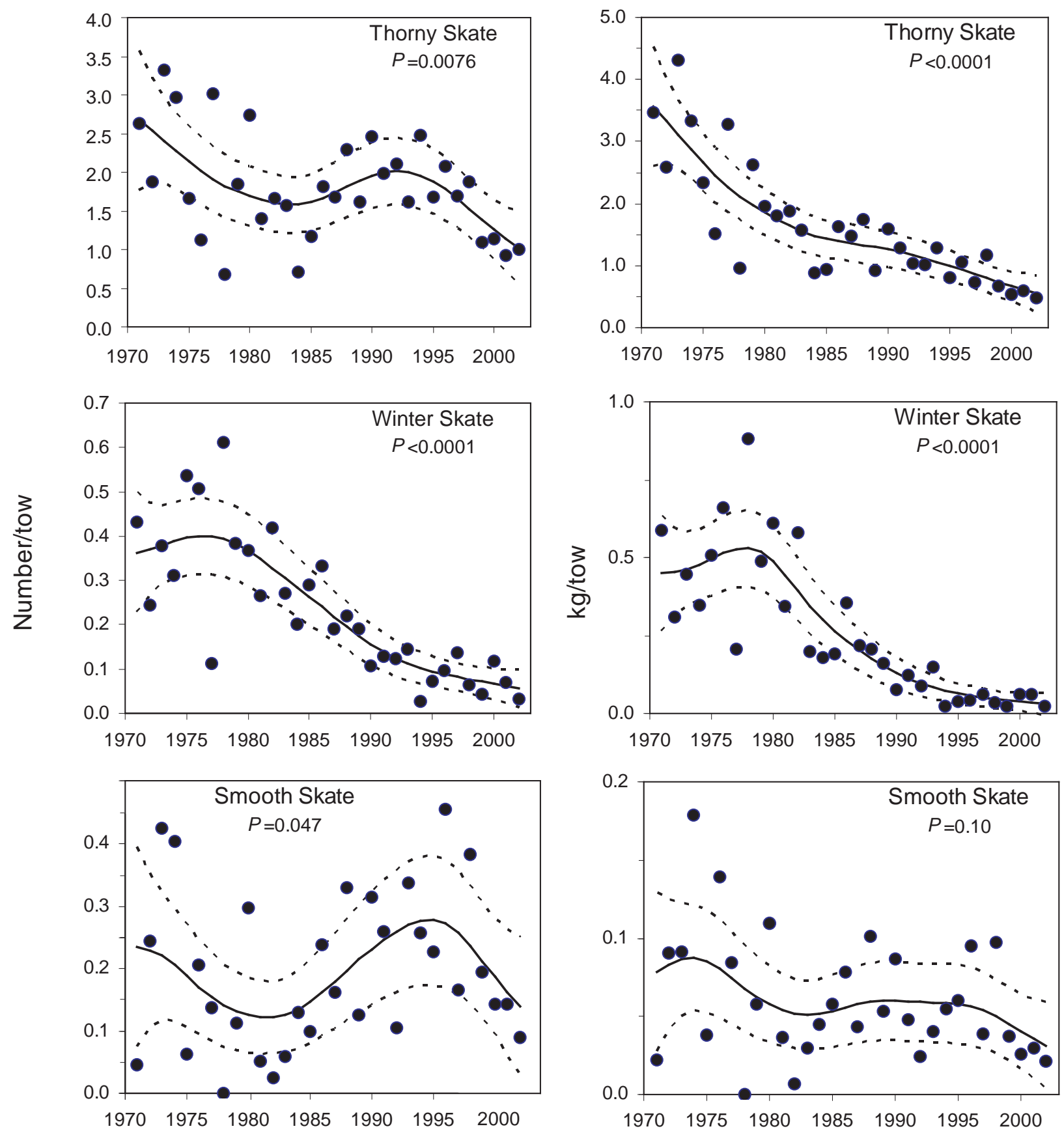

Fig. 2. Relative abundance (fish/tow) and biomass (kg/tow) of thorny, winter and smooth skate in the southern Gulf of St. Lawrence in September, 1971-2002. Solid line is a GAM fit to the data, and dashed lines are the approximate $95 \%$ confidence intervals. $P$ is the significance of the GAM.

Abundance trends by size-class (Fig. 3) identify the reason for the contrasting trends between overall abundance and biomass of thorny and smooth skates. The abundance of small skates ( $<33 \mathrm{~cm}$ in length) increased from the mid-1980s to a peak in the mid-1990s for both thorny and smooth skate. In contrast, no changes in the abundance of small individuals were evident for winter skate. Medium-sized skates $(33-50 \mathrm{~cm}$ ) declined in abundance from 1971 to 2002 for both thorny and winter skate but not for smooth skate. For winter skate this decline occurred over most of the period, whereas for thorny skate it was restricted to the early 1970s and the 1990s. 
TABLE 1. Exponential decay models fit to skate abundance and biomass trends. $\delta$ is the estimated rate of decline, and SE its standard error. $\Delta$ is the estimated percent decline over the 32-year time series.

\begin{tabular}{lcccc}
\hline \hline & $\delta$ & SE & P & \\
\hline A. Biomass & & & & \\
Thorny skate & 0.0563 & 0.0073 & $<0.0001$ & 83.5 \\
Winter skate & 0.0645 & 0.0134 & $<0.0001$ & 87.3 \\
Smooth skate & 0.0211 & 0.0124 & 0.099 & 49.1 \\
B. Abundance (fish over 50 cm in length) & & & & \\
Thorny skate & & & $<0.0001$ & 89.8 \\
Winter skate & 0.0712 & 0.0095 & $<0.0001$ & 90.1 \\
Smooth skate & 0.0723 & 0.0153 & 0.032 & 73.6 \\
\hline
\end{tabular}

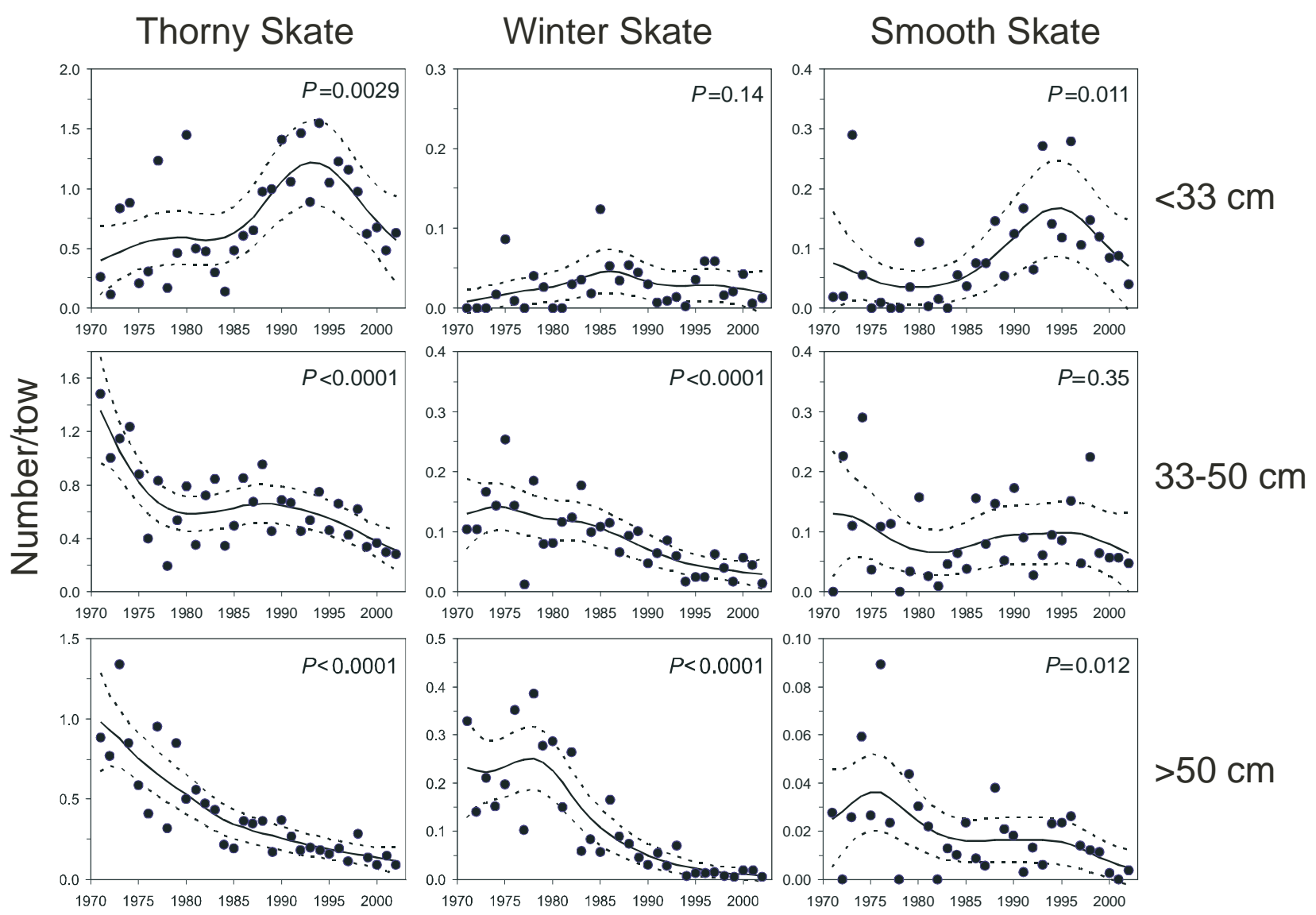

Fig. 3. Relative abundance of thorny, winter and smooth skate by length class. Solid line is a GAM fit to the data, and dashed lines are the approximate $95 \%$ confidence intervals. $P$ is the significance of the GAM.

Large skates declined in abundance for all three species, though declines were much more significant for thorny and winter skate than for smooth skate (Fig. 3, Table 1). Abundance of large (mature) skates declined by $90 \%$ over the 32-year period for both thorny and winter skate, and by $74 \%$ for smooth skate (Table 1 ).

\section{Size Composition}

Mean length declined substantially over the time series, decreasing by $20-30 \%$ during the 1980 s for each of the three species (Fig. 4). For winter skate, this decline in mean size was entirely due to a decrease in the abundance of large fish (Fig. 5). In contrast, for smooth 

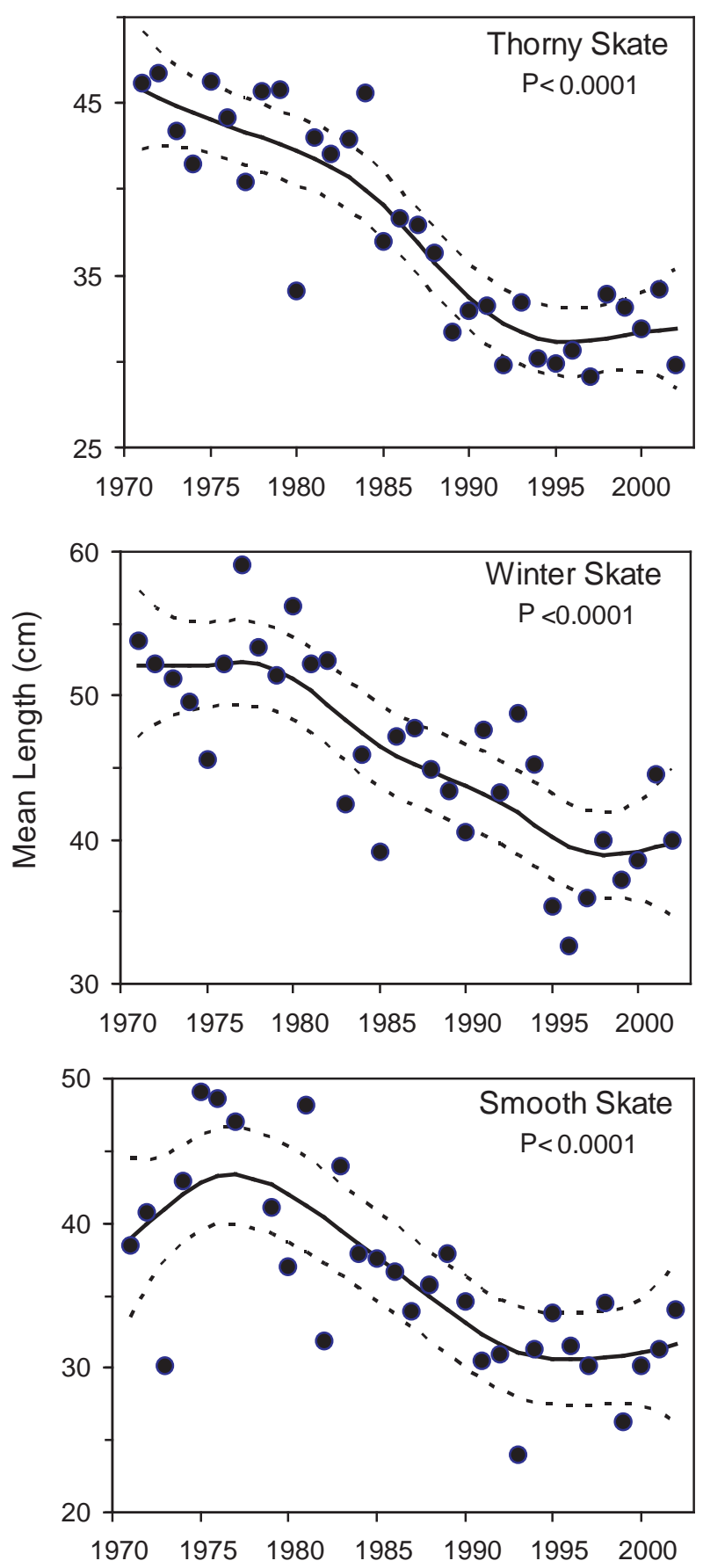

Fig. 4. Mean length of thorny, winter and smooth skate in the southern Gulf of St. Lawrence in September, 1971-2002. Solid line is a GAM fit to the data, and dashed lines are the approximate $95 \%$ confidence intervals. $P$ is the significance of the GAM.

skate, this decline was mainly due to the increase in abundance of small fish in the 1990s, though a decrease in the abundance of large fish from the 1970s to the 1980s also contributed to the decline in mean size. For thorny skate,
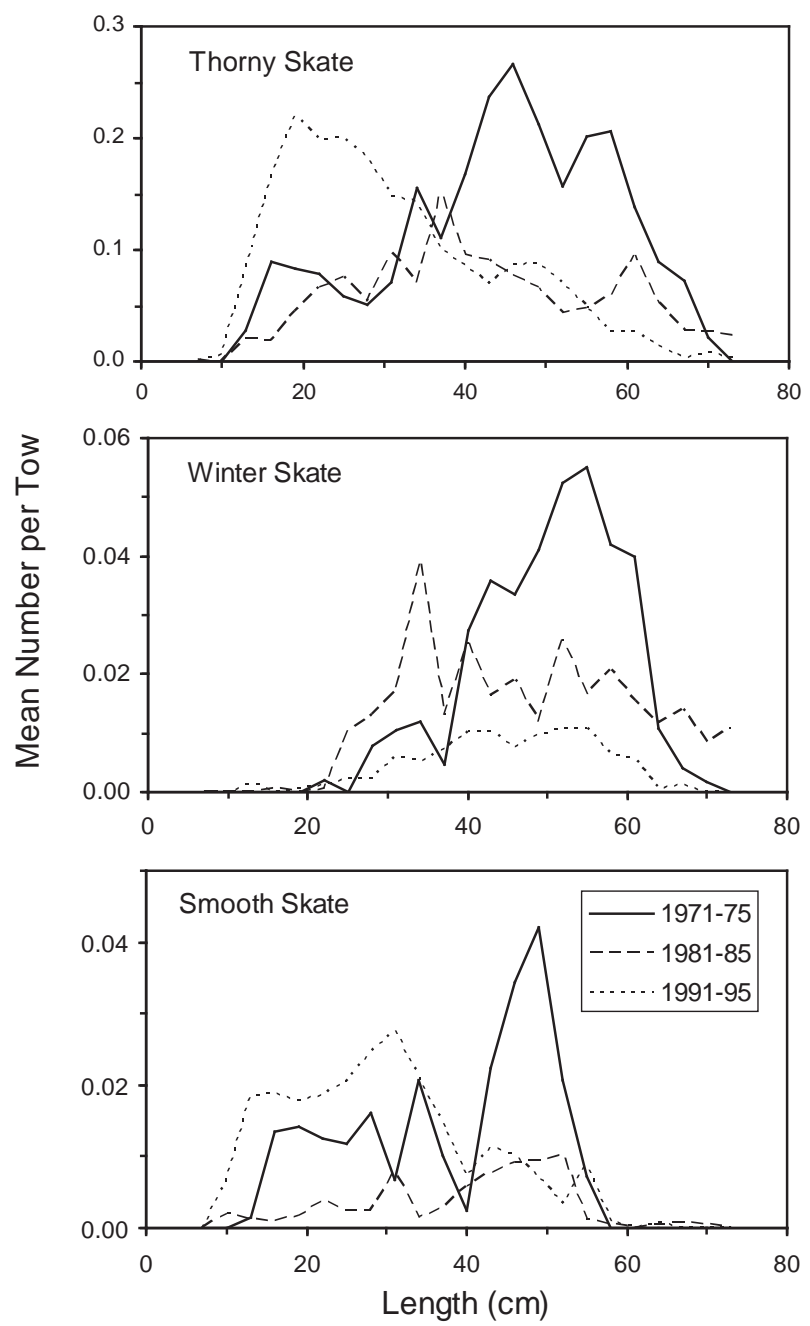

Fig. 5. Length distributions of thorny, winter and smooth skate catches in the September survey of the southern Gulf of St. Lawrence in three 5-year blocks.

both a decrease in the abundance of large fish from the 1970s to the 1980s and an increase in the abundance of small fish from the 1980s to the 1990s contributed to the decline in mean size.

\section{Potential Explanatory Factors}

Our attempts to understand causes of the changes in skate abundance and size composition focused on two contrasting patterns: the increase in the abundance of small thorny and smooth skates in the mid-1990s, and the decrease in the abundance of large thorny and winter skate over the 32-year time period. In order to simplify this analysis, we reduced each of these patterns to a single common trend, estimated using DFA (Fig. 6a and b). In both cases, the common trend was closely correlated with each of the original time series. Correlations between the abundances of small thorny and smooth skates and their 

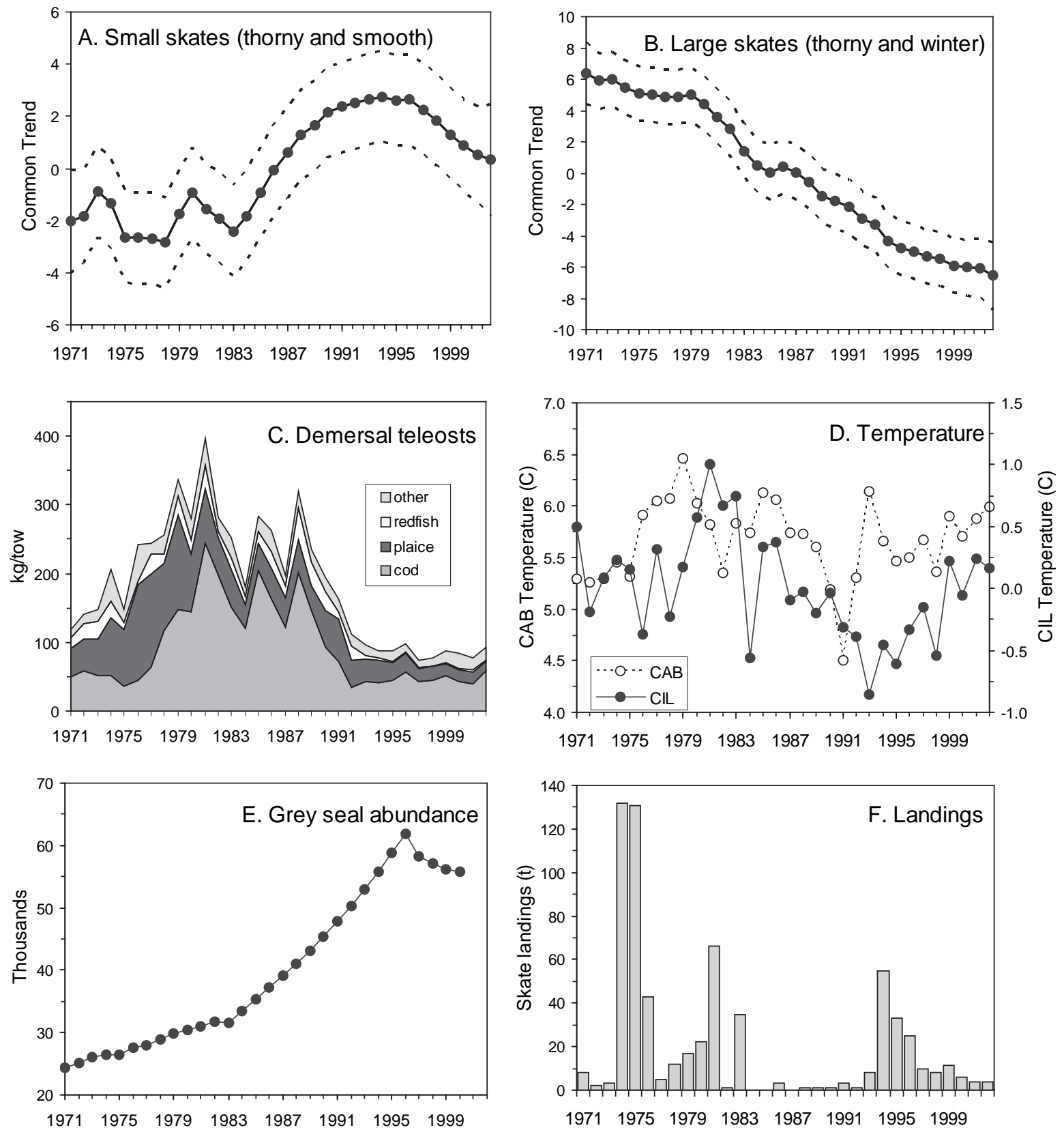

Fig. 6. Common trends in skate abundance and time series of potential explanatory factors: (A) common trend in the abundance of small ( $<33 \mathrm{~cm}$ TL) thorny and smooth skate; (B) common trend in the abundance of large ( $>50 \mathrm{~cm}$ TL) thorny and winter skate; (C) biomass trends for demersal teleosts in the southern Gulf of St. Lawrence; (D) temperature indices: CAB, the average temperature of the 200-300 m layer along the standard Cabot Strait section; CIL, the minimum CIL temperature index for the Magdalen Shallows; (E) abundance of the Gulf grey seal herd; (F) reported skate landings in the southern Gulf. Dashed lines in panels (A) and (B) are 95\% confidence intervals.

common trend were 0.73 and 0.77 , respectively. For large thorny and winter skate, correlations with their common trend were 0.89 and 0.92 , respectively.

A strong negative correlation occurred between the two common trends, with the trend for large skates lagged
0-8 years behind the trend for small skates (Fig. 7a). This would be consistent with increased production or survival of juvenile skates when adult skate abundance is low.

Survey catch rates of demersal teleosts were relatively low in the early 1970s, increased to high levels from the 


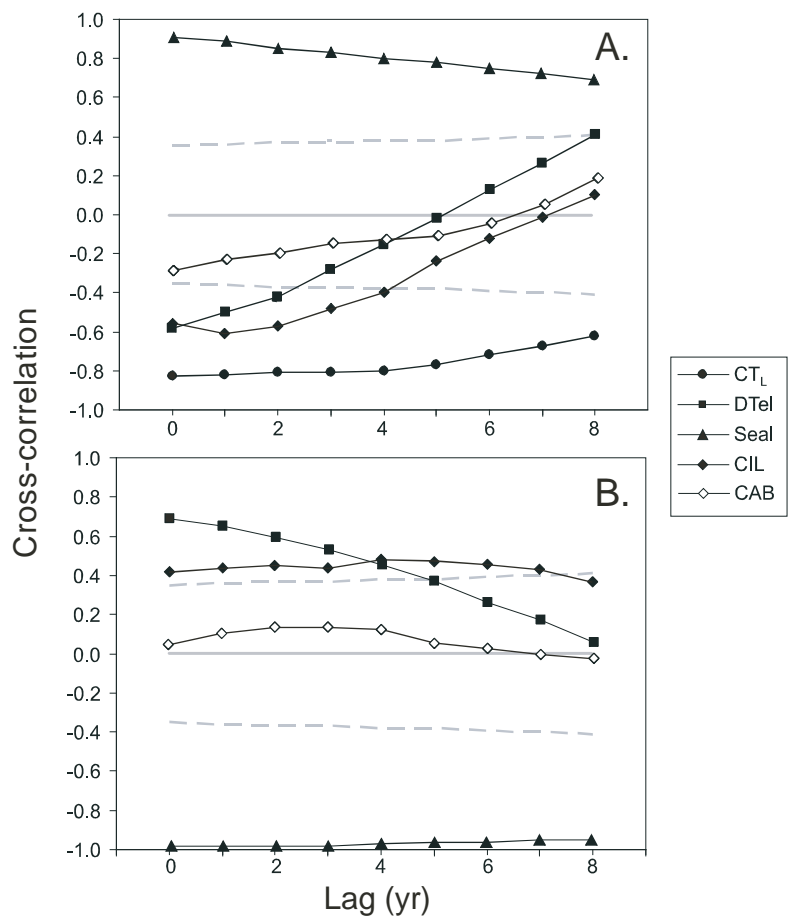

Fig. 7. Cross-correlations between the common trends for (A) small thorny and smooth skates or (B) large thorny and winter skates and potential explanatory factors: $\mathrm{CT}_{\mathrm{L}}$, the common trend for large skates; DTel, the biomass index for demersal teleosts; Seal, the grey seal abundance index; CIL, the CIL minimum temperature index; and CAB, average temperature in the 200-300 m layer along the Cabot Strait section. Correlations are for the explanatory variable lagged 0 to 8 years behind the common trend. Correlations more extreme than the dashed grey lines are nominally significant.

mid-1970s to the late 1980s, and then declined rapidly to low levels throughout the 1990s (Fig. 6c). Most of the biomass of demersal teleosts caught in the survey consists of cod and plaice. Plaice biomass was high from the midto late 1970s and then declined. Cod biomass was low in the mid-1970s, rose rapidly to high levels throughout the 1980s, and then declined rapidly to low levels throughout the 1990s. A strong negative correlation occurred between the biomass of demersal teleosts and the abundance of small skates at lags of $0-2$ years, but not at greater lags (Fig. 7a). This suggests that reduced predation by demersal teleosts such as cod may contribute to the increased abundance of small skates in the mid-1990s. On the other hand, a strong positive correlation occurred between demersal teleost biomass and the abundance of large skates at lags of $0-4$ years (Fig. 7b). This is not consistent with competitive or predatory interactions between the two groups, but instead suggests that both may be similarly affected by a common factor.
CIL temperature in the southern Gulf of St. Lawrence was warm in the early 1980s and cold in the early to mid-1990s (Fig. 6d). CIL temperature was negatively correlated with the abundance of small skates at lags of $0-4$ years and positively correlated with abundance of large skates at all lags examined (Fig. 7). Temporal trends in the temperature of the deep waters of the Cabot Strait were less distinct. The pronounced cooling that was evident in CIL waters in the early to mid-1990s was not evident in these deep waters, except briefly in the early 1990s. Correlations between skate abundance and temperatures in these deep waters were weak at all lags, especially for large skates (Fig. 7).

Grey seal abundance in the southern Gulf of St. Lawrence rose steadily throughout the 1970 s and 1980 s to a peak in 1996 (Fig 6e). Since then, the abundance of grey seals in the southern Gulf has declined slightly, though their abundance remains high compared to levels observed in the 1970s and 1980s. At all lags, grey seal abundance was positively correlated with the abundance of small skates and negatively correlated with the abundance of large skates (Fig. 7).

\section{Discussion}

Catch rates (kg/tow) of thorny and winter skates have declined dramatically in the September survey of the southern Gulf of St. Lawrence, decreasing by 80-90\% over the past 32 years. We have interpreted these trends in survey catch rates as indicating a sharp decline in population biomass for both species in the southern Gulf. An alternative interpretation could be that these trends reflect changes in the seasonal distribution of skates, with increasing proportions of these populations distributed outside of the survey area in September in recent years. Earlier autumn migrations to overwintering grounds outside of the Gulf of St. Lawrence have been reported for both the northern and southern Gulf cod populations in the 1990s (Castonguay et al., 1999; Comeau et al., 2002). The decline in survey catch rates of thorny skate might likewise reflect an earlier autumn migration to overwintering grounds in the deep waters of the Laurentian Channel. However, based on a comparison of skate catches in the September survey and in a July/August survey of the Magdalen Shallows, Swain and Benoît (in press) ruled out an earlier autumn migration as a cause of recent changes in the distribution of thorny skate in the southern Gulf of St. Lawrence. Furthermore, densities of thorny skate were very low in the deep waters of the Laurentian Channel in late summer and early autumn throughout the 1990s (Swain and Benoît, in press; Swain, unpubl. data), indicating that the bulk of the thorny skate population occurred within the survey area in September 
even in recent years. In contrast to thorny skate, winter skate are distributed along the inshore margin of the survey area (Fig. 1). An unknown portion of the winter skate population occurs inshore of the survey area. However, it is unlikely that declines in winter skate biomass in the September survey can be attributed to changes in seasonal migrations. Winter skate move offshore in late autumn, becoming widely distributed over the Magdalen Shallows in winter (Clay, 1991; Darbyson and Benoît, 2003). Thus, an earlier autumn migration by winter skate in recent years would increase their availability to the September survey, resulting in an increase rather than a decrease in survey catch rates. For both species, the decline in survey catch rates appears to reflect a decline in population biomass rather than changes in seasonal movements.

Both common trends in skate abundance were strongly correlated with grey seal abundance. Correlations were negative for large skates but positive for small skates. Because grey seal predation is thought to be concentrated on small fish (e.g., Bowen et al., 1993), these correlations do not appear consistent with a causal link between grey seal predation and skate abundance.

The decline in the abundance of large skates may be an effect of fishing. Reported landings of skates from the southern Gulf of St. Lawrence have always been low (Fig. $6 f)$. However, reported landings are a small fraction of the actual catches of skates. Most of the skate catch is discarded at sea. Based on observed by-catch rates in southern Gulf of St. Lawrence fisheries, estimated annual catches of skates in the southern Gulf were 1 500-2 000 tonnes in the early 1990s and 600-900 tonnes in the mid- to late 1990s (Benoît, unpubl. data). Although it has been suggested that discard mortality is relatively low for skates (Fogarty and Murawski, 1998; Walker and Hislop, 1998), empirical studies indicate mortality rates of $40 \%$ or greater (Laptikhovsky, 2004). Fishing effort in the southern Gulf increased dramatically in the 1950s, following the lifting of a ban on otter trawling in the late 1940s (Chouinard and Fréchet, 1994). The declining abundance of large skates, evident since the start of the survey time series in 1971, may reflect a slow but steady depletion of these skates in response to the increased fishing effort beginning in the 1950s. Fishing effort declined sharply in the southern Gulf of St. Lawrence with the closure of the cod fishery in 1993 (Chouinard et al. MS 2003). A decade later, no recovery in the abundance of large skates is yet evident.

The increase in the abundance of juvenile smooth and thorny skates in the 1990s coincided roughly with a collapse in the biomasses of large-bodied demersal teleost fishes and large skates, a dramatic decline in fishing effort, and a cooling of the CIL in the southern Gulf of St. Lawrence. Reduced predation by demersal fishes and reduced by-catch mortality in fisheries may have contributed to the increase in juvenile skate abundance in the early to mid-1990s. However, these factors alone cannot account for the trends in juvenile skate abundance. Juvenile skates began to increase in abundance in the mid- to late 1980s, when demersal teleost biomass was high (Fig. 6c) and fishing effort increased to very high levels (Chouinard et al., MS 2003). The abundance of small skates showed a close negative correlation with the CIL temperature index, with abundance increasing as the CIL cooled in the late 1980s and early 1990s and decreasing as it warmed in recent years. However, it is unclear whether this correlation reflects a causal connection between CIL temperatures and the survival of small skates. In particular, smooth skates occur mostly in the warm deep waters below the CIL (Fig. 1). Likewise, thorny skates have also become most concentrated in deep waters below the CIL in the 1990s (Swain and Benoît, in press). The prolonged cooling, evident in the CIL from the late 1980s to the late 1990s, did not occur in these deep waters (Fig. 6d).

The biomass of small elasmobranchs (skates and spiny dogfish) increased throughout the 1980s on Georges Bank, coincident with the collapse of heavily exploited groundfish stocks (Fogarty and Murawski, 1998). It has been suggested that this represents a case of species replacement caused in part by fishing pressure (e.g., Hall, 1999). In contrast, exploited gadoid species have not been replaced by elasmobranchs in the North Sea, though thorny skate (starry ray) does appear to have increased in abundance in this area (Walker and Hislop, 1998). Hall (1999) suggested that this contrast may reflect differences in the exploitation of elasmobranchs. On Georges Bank these species were generally discarded in the 1980s whereas they are often landed in the North Sea, except for thorny skate. However, the southern Gulf presents a case where depleted groundfish stocks have not been replaced by elasmobranch species even though these species are generally discarded at sea in this area.

No recovery in the abundance of mature skates is evident despite sharply reduced fishing effort in the southern Gulf of St. Lawrence over the past decade. The increased abundance of juvenile skates in the early to mid-1990s may be partly attributable to the reduced fishing effort or collapsed groundfish stocks during this period. However, there has been no indication of the recruitment of these small individuals to larger sizes, pointing to either very high mortality rates or slow growth rates for these fish. Furthermore, even these juvenile skates have declined in abundance since the mid-1990s. Finally, distribution of the 
most common of these skates, the thorny skate, has contracted sharply in recent years. These skates, once widely dispersed throughout the southern Gulf of St. Lawrence in September, are now mostly confined to the relatively deep waters along the slope of the Laurentian Channel and in the Cape Breton Trough (Swain and Benoît, in press).

\section{Acknowledgements}

We thank Denis Gilbert (Institut Maurice-Lamontagne, Mont-Joli, Québec) and Roger Pettipas (Bedford Institute of Oceanography, Dartmouth, Nova Scotia) for providing the indices of environmental conditions, and Ghislain Chouinard and two anonymous reviewers for providing comments on an earlier version of this work.

\section{References}

BENOÎT, H. P., and D. P. SWAIN. 2003a. Standardizing the southern Gulf of St. Lawrence bottom-trawl survey time series: adjusting for changes in research vessel, gear and survey protocol. Can. Tech. Rep. Fish. Aquat. Sci., 2505: iv +95 p.

2003b. Accounting for length- and depth-dependent diel variation in catchability of fish and invertebrates in an annual bottom-trawl survey. ICES J. Mar. Sci., 60: $1298-1317$.

BOWEN, W. D., J. W. LAWSON, and B. BECK. 1993. Seasonal and geographic variation in the species composition and size of prey consumed by grey seals (Halichoerus grypus) on the Scotian Shelf. Can. J. Fish. Aquat. Sci., 50: $1768-1778$.

BRANDER, K. 1981. Disappearance of common skate Raia batis from the Irish Sea. Nature, 290: 48-49.

CASEY, J. M., and R. A. MYERS. 1998. Near extinction of a large, widely distributed fish. Science, 281: 690-692.

CASTONGUAY, M., C. ROLLET, A. FRÉCHET, P. GAGNON, D. GILBERT, and J.-C. BRÊTHES. 1999. Distribution changes of Atlantic cod (Gadus morhua) in the northern Gulf of St. Lawrence in relation to an oceanic cooling. ICES J. Mar. Sci., 56: 333-344.

CHOUINARD, G. A., and A. FRÉCHET. 1994. Fluctuations in the cod stocks of the Gulf of St. Lawrence. ICES Mar. Sci. Symp., 198: 121-139.

CHOUINARD, G. A., D. P. SWAIN, L. CURRIE, G. POIRIER, A. RONDEAU, H. BENOÎT, T. HURLBUT, and D. DAIGLE. MS 2003. Assessment of cod in the southern Gulf of St. Lawrence, February 2003. CSAS Res. Doc., No. 2003/015, 116 p.

CHOUINARD, G. A., D. P. SWAIN, M. O. HAMMILL, and G. A. POIRIER. 2005. Covariation between grey seal (Halichoerus grypus) abundance and natural mortality of cod (Gadus morhua) in the southern Gulf of St. Lawrence. Can. J. Fish. Aquat. Sci., 62: (in press).

CLAY, D. 1991. Seasonal distribution of demersal fish (Osteichthyes) and skates (Chondrichthyes) in the southeastern Gulf of St. Lawrence. Can. Spec. Publ. Fish. Aquat. Sci., 113: 241-259.
COMEAU, L. A., S. E. CAMPANA, and G. A. CHOUINARD. 2002. Timing of Atlantic cod (Gadus morhua L.) seasonal migrations in the southern Gulf of St. Lawrence: interannual variability and proximate control. ICES J. Mar. Sci., 59: 333-351.

DARBYSON, E., and H. P. BENOÎT. 2003. An atlas of the seasonal distribution of marine fish and invertebrates in the southern Gulf of St. Lawrence. Can. Data Rep. Fish. Aquat. Sci., 1113: 294 p.

DRINKWATER, K.F., and D. GILBERT. 2004. Hydrographic variability in the waters of the Gulf of St. Lawrence, the Scotian Shelf and the eastern Gulf of Maine (NAFO Subarea 4) during 1991-2000. J. Northw. Atl. Fish. Sci., 34: 83-99.

FRISK, M. G., T. J. MILLER, and N. K. DULVY. 2005. Life histories and vulnerability to exploitation of elasmobranchs: inferences from elasticity, perturbation and phylogenetic analyses. J. Northw. Atl. Fish. Sci., 35: 27-45.

FOGARTY, M. J., and S. A. MURAWSKI. 1998. Large-scale disturbance and the structure of marine ecosystems: fishery impacts on Georges Bank. Ecol. Appl., 8: S6-S22.

GILBERT, D., and B. PETTIGREW. 1997. Interannual variability (1948-1994) of the CIL core temperature in the Gulf of St. Lawrence. Can. J. Fish. Aquat. Sci., 54(Suppl. 1): $57-67$.

HALL, S. J. 1999. The effects of fishing on marine ecosystems and communities. Blackwell Science, Oxford, 274 p.

HAMMILL, M. O., and G. B. STENSON. 2000. Estimated prey consumption by harp seals (Phoca groenlandica), hooded seals (Cystophora cristata), grey seals (Halichoerus grypus) and harbour seals (Phoca vitulina) in Atlantic Canada. J. Northw. Atl. Fish. Sci., 26: 1-23.

HAMMILL, M. O., and G. B. STENSON. MS 2002. Estimated consumption of Atlantic cod (Gadus morhua) and some other prey by grey seals (Halichoerus grypus) and harp seals (Phoca groenlandica) in the southern Gulf of St. Lawrence (NAFO Division 4T). CSAS Res. Doc., No. 2002/054, 34 p.

HEESEN, H. J. L., and N. DAAN. 1996. Long-term trends in ten non-target North Sea fish species. ICES J. Mar. Sci., 53: 1063-1078.

HOLDEN, M. J. 1973. Are long-term fisheries for elasmobranchs possible? ICES Rapp. Proc.-Verb., 164: 360-367.

LAPTIKHOVSKY, V. V. 2004. Survival rates for rays discarded by the bottom trawl squid fishery off the Falkland Islands. Fish. Bull. 102: 757-759.

MATHSOFT. 1999. S-Plus 2000: Guide to Statistics, Vol. 1. MathSoft, Inc. Seattle, WA.

McEACHRAN, J. D., and C. O. MARTIN. 1977. Possible occurrence of character displacement in the sympatric skates Raja erinacea and R. ocellata (Pisces: Rajidae). Env. Biol. Fishes, 2: 121-130.

MURAWSKI, S. A., and J. S. IDOINE. 1992. Multispecies size composition: a conservative property of exploited fishery systems? J. Northw. Atl. Fish. Sci. 14: 79-85.

NIELSEN, G. A. 1994. Comparison of the fishing efficiency of research vessels used in the southern Gulf of St. Lawrence groundfish surveys from 1971 to 1992. Can. Tech. Rep. Fish. Aquat. Sci., 1952: 56 p. 
SIMON, J. E., and K. T. FRANK. MS 1996. Assessment of the Division 4VsW Skate Fishery. DFO Atl. Fish. Res. Doc., No. 96/105: $51 \mathrm{p}$.

STEVENS, J. D., R. BONFIL, N. K. DULVY, and P. A. WALKER. 2000. The effects of fishing on sharks, rays, and chimaeras (chondrichthyans), and the implications for marine ecosystems. ICES J. Mar. Sci., 57: 476-494.

SWAIN, D. P., and H. P. BENOÎT. (in press). Change in habitat associations and geographic distribution of thorny skate (Amblyraja radiata) in the southern Gulf of St. Lawrence: density-dependent habitat selection or response to environmental change? Fish. Oceanogr.

TEMPLEMAN, W. 1987. Differences in sexual maturity and related characteristics between populations of thorny skate (Raja radiata) in the northwest Atlantic. J. Northw. Atl.
Fish. Sci., 7: 155-167.

VENABLES, W. N., and B. D. RIPLEY. 1994. Modern applied statistics with S-Plus. Springer-Verlag, New York, p. 187.

WALKER, P. A., and H. J. L. HEESEN. 1996. Long-term changes in ray populations in the North Sea. ICES J. Mar. Sci., 53: 1085-1093.

WALKER, P. A., and J. R. G. HISLOP. 1998. Sensitive skates or resilient rays? Spatial and temporal shifts in ray species composition in the central and north-western North Sea between 1930 and the present day. ICES J. Mar. Sci., 55: 392-402.

ZUUR, A. F., I. D. TUCK, and N. BAILEY. 2003. Dynamic factor analysis to estimate common trends in fisheries time series. Can. J. Fish. Aquat. Sci., 60: 542-552. 